\title{
CHANGING DEVELOPMENT PATH OF QUAESTIONES GEOGRAPHICAE IN THE FIELD OF HUMAN GEOGRAPHY AND SPATIAL MANAGEMENT
}

This volume of Quaestiones Geographicae allows me to announce that this December marks the end of my 15-year run as Managing Editor of the journal in the field of Human Geography and Spatial Management. Established in 1974 as an annual of the then Institute of Geography of Adam Mickiewicz University in Poznań, Quaestiones Geographicae has undergone several turns of fate in its 47-year history; in the difficult times of the post-socialist transformation, the journal even had a break of several years in its activity. When I was appointed as Director of the Institute of Socio-Economic Geography and Spatial Management in 2005 (shortly after the enlargement of the European Union), I recognised that the new geopolitical situation required an expansion of existing channels of international geographical knowledge exchange, especially in relation to post-socialist transformation processes and other new global megatrends. This understanding provided a basis for the founding of series B of Quaestiones Geographicae focused on Human Geography and Spatial Management. Under my editorship since 2006, each issue of this series has been published alongside the issues of series A on Physical Geography and Geoinformation (likewise Geografiska Annaler or Bulletin of Geography). However, in 2009, the newly appointed Institute's authority with its director, Professor Waldemar Ratajczak, unexpectedly decided to end this thriving editorial activity and replace it with a new journal, established under his editorship, titled Badania Fizjograficzne. Seria D - Gospodarka Przestrzenna (Physiographic Research. Series D Spatial Management). Fortunately, this decision (the motives of which remain unclear) ${ }^{1}$ was partially thwarted and socio-economic geography topics continued to be discussed in Quaestiones Geographicae, albeit in a slightly modified form: with one chief editorship and two thematically profiled versions: blue (for Physical Geography and Geoinformation) and green (for Human Geography and Spatial Management), each of them issued twice a year. Since then, Quaestiones Geographicae has been published in this form, holding a high position among English-language periodicals in East-Central Europe.

Over this 15-year period, the entire editorial team have engaged in numerous activities aimed at increasing the prestige and international impact of the journal and ensuring that publication procedures meet contemporary standards. The most noteworthy actions include the introduction of the journal to the publishing platform de Gruyter, followed by Sciendo, in addition to numerous world databases. The journal's growing global exposure has been accompanied by steady growth in the citation rate of its articles. Had it not been for the impeccable collaboration of the entire editorial team (with its Editorin-Chief Professor Andrzej Kostrzewski), the International Advisory Board, and the involvement of numerous reviewers who spared no time to assist in publishing, these achievements would not have been possible. I would like to express my gratitude to everyone involved for their hard work and commitment to our journal as well as their ongoing kindness and support.

In January 2022, the position of Managing Editor of the volumes in the field of Human

\footnotetext{
The newly-created periodical ceased publication after only two issues.
} 
Geography and Spatial Management will be handed over to a younger generation. The present Executive Editor, Professor Joanna Dominiak, will take over; in turn, her responsibilities as Executive Editor will be assumed by Professor Krzysztof Stachowiak. I wish them every success in the continued growth of Quaestiones Geographicae and great satisfaction in their new roles.

This changeover follows the institutional transformation in Polish geography which started in 2018. I write more about these developments in the article "Emergence of socio-economic geography and spatial management as a scientific discipline in the new classification of science in Poland", which opens this issue of Quaestiones Geographicae.

Our journal has always been open to the achievements of young scholars in geography and related sciences. This is manifested in the following two articles; both of which are authored by Early Stage Researchers of the Marie Skłodowska-Curie European Training Network "Re-City: Reviving shrinking cities - innovative paths and perspectives towards livability for shrinking cities in Europe" funded by the EU's Horizon 2020 programme. The first, by Flavio Besana, starts a discussion on demographic shrinkage and its perception among EU citizens. The second, by David Huntington, picks up on this discussion by exploring the relationship between urban shrinkage and socio-economic segregation in the context of medium-sized cities.
In the next article, Galina Kapachinska takes us to a hotspot of contemporary geopolitical changes; namely, to Ukraine. The author analyses both historical determinants and specificity of the current geopolitical transformation. The subsequent article by Shukhrat Kurbanov Bekmetovich and Medetbay Oteuliev Orinbayevich shows territorial differences in living standards in another post-Soviet state, the Republic of Uzbekistan.

Three successive articles address the issue of sustainable tourism and tourists' travel motivations in three very different geographical areas: Romania (by Loredana Dragomir and Mirela Mazilu), Malavi (by Felix Gasten Bello), and Iran (by Yaser Ramazannejad, Moslem Zarghamfard, Arezzo Hajisharifi, and Sahand Azar). The first article in this group examines a topical issue of note: the metamorphosis of tourism following the COVID-19 pandemic.

The last article deals with the effects of human activities on the environment. Fernando Luiz Camacho Martins, Fabio Giordano, and Walter Barella discuss the problem of social and environmental vulnerability in the estuary of the metropolitan region of Santos in Brazil.

Summing up, the articles published in this issue analyse a vast scope of topics across a variety of geographical contexts, including Europe, Asia, Africa, and South America. I trust they will be well received by readers.

Tadeusz Stryjakiewicz Managing Editor

Human Geography and Spatial Management 